\title{
Perubahan Perilaku Komunikasi Generasi Milenial dan Generasi Z di Era Digital
}

\author{
Sirajul Fuad Zis ${ }^{\mathrm{a}, 1^{*}}$, Nursyirwan Effendib,2, Elva Ronaning Roemc $\mathrm{c} 3$ \\ abc Universitas Andalas, Jalan Situjuh Padang, Jati Baru, Kota Padang, Sumatera Barat, 25129, Indonesia \\ ${ }^{1}$ sirajulfuadz@gmail.com; ${ }^{2}$ neffendi_99@yahoo.com; ${ }^{3}$ elvarona80@gmail.com
}

${ }^{*}$ Corresponding Author

\begin{tabular}{ll}
\hline INFO ARTIKEL & ABSTRAK \\
\hline Sejarah Artikel: & Pada era digital, terjadi perubahan perilaku komunikasi generasi milenial dan \\
Diterima: 10 Februari 2021 & generasi Z. Perubahan tersebut dapat dilihat dalam kehidupan sehari-hari, \\
Direvisi: 4 Maret 2021 & seperti kurangnya interaksi tatap muka karena kehadiran gawai. Fenomena \\
Disetujui: 19 Maret 2021 & ini juga terjadi pada generasi milenial dan generasi Z di Kecamatan Kuranji. \\
Tersedia Daring: 10 April 2021 & Penelitian ini bertujuan mendeskripsikan perilaku komunikasi milenial dan \\
\hline Kata Kunci: & generasi Z di Kecamatan Kuranji danmelihat degradasi komunikasi \\
Era Digital & antarmuka yang terjadi. Adapun teori yang digunakan adalah perilaku \\
Gen Z & komunikasi, komunikasi interpersonal, komunikasi generasi milenial, \\
Milenial & komunikasi generasi Z, media baru, dan behaviorisme sosial. Penelitian ini \\
Perilaku Komunikasi & menggunakan pendekatan fenomenologi Alfred Schutz dengan paradigma \\
& konstruktivisme. Penelitian ini menganalisis perilaku komunikasi generasi \\
& milenial dan generasi Z era digital di Kecamatan Kuranji dari sepuluh orang \\
& informan. Hasil penelitian menunjukkan empat perilaku generasi milenial \\
& dan generasi Z terbentuk di Kecamatan Kuranji, yaitu perilaku komunikasi \\
& dari aktif menjadi pasif disebabkan oleh gawai, berkurangnya komunikasi \\
& tatap muka disebabkan oleh gawai, tidak fokus dalam berkomunikasi \\
& disebabkan oleh gawai, dan perilaku komunikasi daring disebabkan oleh \\
& gawai. Dalam penelitian ini, dapat ditarik kesimpulan bahwa perilaku \\
& generasi milenial dan generasi Z yang semula interaktif sebelum \\
& menggunakan gawai, setelah menggunakan gawai proses komunikasinya \\
& menjadi pasif, sehingga tidak terjadi komunikasi efektif.
\end{tabular}

\begin{tabular}{ll}
\hline & ABSTRACT \\
\hline Keywords: & In the digital era, there has been a change in the communication behavior of \\
Digital Era & millennial generation and generation Z. These changes can be seen in \\
Gen $Z$ & everyday life, such as the lack of face-to-face interaction due to the presence \\
Millennial & of devices. This phenomenon also occurs in the millennial generation and \\
Communication Behavior & generation $Z$ in Kuranji District. This study aims to describe the \\
communication behavior of millennials and generation $Z$ in Kuranji District \\
and to see the degradation of communication interfaces that occurs. The \\
theories used are communication behavior, interpersonal communication, \\
millennial generation communication, generation $Z$ communication, new \\
media, and social behaviorism. This study used Alfred Schutz's \\
phenomenological approach with the constructivism paradigm. This study \\
analyzes the communication behavior of the millennial generation and \\
generation $Z$ in the digital era in Kuranji District from ten informants. The \\
results showed that four millennial generation and generation $Z$ behaviors \\
were formed in Kuranji District, namely communication behavior from \\
active to passive caused by devices, reduced face-to-face communication \\
caused by devices, not focusing on communication caused by devices, and \\
online communication behavior caused by devices. In this study, it can be \\
concluded that the behavior of the millennial generation and generation $Z$, \\
which was originally interactive before using a device, after using a device \\
the communication process becomes passive, so there is no effective \\
communication.
\end{tabular}




\section{Pendahuluan}

Pengelompokkan generasi muncul dalam dunia kerja berdasarkan sumber daya manusia. Penelitian terkait perbedaan generasi ini pertama kali dilakukan oleh Manheim (Budiati, 2018). Menurutnya generasi adalah konstruksi sosial yang di dalamnya terdapat sekelompok orang yang memiliki umur dan pengalaman historis yang sama (Budiati, 2018). Kebiasaan setiap generasi juga punya karakteristik masingmasing sesuai dengan perkembangan zaman. Howe dan Strauss (Zorn, 2017) mendefinisikan generasi milenial sebagai generasi yang kaya, berpendidikan lebih baik, beragam etnis, dan fokus pada kerja tim, prestasi, kesederhanaan, dan perilaku yang baik.

Milenial memiliki kemampuan bawaan menguasai teknologi, seperti kemampuan multitasking dalam penggunaan perangkat digital. Menurut pendapat populer, karakteristik Gen $\mathrm{Z}$ adalah tingginya pemahaman mereka akan teknologi. Hal ini karena sejak lahir sudah bersentuhan dengan gawai (Zorn, 2017). Gen Z merupakan orang yang lahir pada kurun 1995-2010. Mereka disebut sebagai penduduk asli digital karena sejak usia dini telah terpapar oleh internet dan telfon genggam (Francis \& Hoefel, 2018).

Istilah generasi milenial pertama kali dicetuskan oleh William dan Neil (Budiati, 2018). Menurutnya generasi milenial adalah orang yang lahir dari rasio tahun 1980-2000 dikenal juga sebagai generasi Y (Budiati, 2018). Generasi milenial memiliki karakter unik berdasarkan wilayah dan kondisi sosial-ekonomi. Salah satu ciri utama generasi milenial ditandai dengan peningkatan penggunaan dan keakraban komunikasi, media dan teknologi digital.
Generasi ini memiliki ciri kreatif dan informatif yang punya passion dan produktivitas sesuai perkembangan kemajuan teknologi.

Sementara itu, ada generasi $Z$ yang lahir setelah generasi milenial mereka lahir rentang tahun 2001 sampai dengan tahun 2010. Generasi $\mathrm{Z}$ atau penduduk asli era digital lahir di dunia digital dengan teknologi lengkap Personal Computer (PC), ponsel, perangkat gaming dan internet. Mereka menghabiskan waktu luang untuk menjelajahi web, lebih suka tinggal di dalam ruangan dan bermain online daripada pergi keluar dan bermain di luar ruangan (Qurniawati \& Nurohman, 2018).

Peralihan generasi ini terjadi saat berkembang pesatnya teknologi global, yang kemudian melahirkan generasi $Z$ punya pola pikir cenderung menginginkan hal serba instan (Budiati, 2018). Gen Z punya keterkaitan erat dengan teknologi, kebutuhan bergantung kepada internet baik di dunia sosial, pendidikan, pengetahuan akan suatu hal yang membuat mereka kaku berkomunikasi di dunia nyata. Untuk selanjutnya generasi milenial dan generasi Z Peneliti sebut milenial dan gen $Z$ dengan pola pikir berbeda generasi tetapi punya kesamaan melek terhadap teknologi.

Sejarah era digital ditandai dengan penggunaan jalur komunikasi secara bersamaan. Semua bentuk media yang mengandalkan kode digital. Perangkat digital untuk menyimpan dan mengedarkan informasi, menjadi sebuah dasar pada komputasi, media, dan telekomunikasi, digital, dipandang sebagai bagian inti dalam mono-media. Dalam bukunya 1999, The Internet Challenge to Televisi, Bruce Owens membuat ramalan konvergensi bahwa melalui digitalisasi, internet akan menjadi 
segalanya, dan televisi, telepon, dan komputer akan bertemu di Internet (Littlejohn \& Foss, 2009).

Kemajuan teknologi hadir untuk mempermudah komunikasi melalui gawai. Media komunikasi gawai telah menjadi kebutuhan mendasar era digital, untuk melakukan koneksi komunikasi jarak jauh dibandingkan dengan penggunaan pos atau telegram yang memerlukan waktu jauh lebih lama menyampaikan pesan (Nasrullah, 2014). Bisa dilihat pada zaman sekarang, begitu mudah mendapatkan informasi terkini yang disebabkan oleh berkembang pesatnya perkembangan teknologi informasi (Fauziyah \& Rina, 2020).

Seperti penelitian yang dilakukan oleh Rizqi dan Pradana tentang dampak penggunaan smartphone bagi kehidupan sosial di Desa Ngadirojo, Kabupaten Pacitan. Mereka mengungkapkan temuan di Ngadirojo, warganya kurang berinteraksi ketika bertemu langsung dalam situasi seperti pertemuan warga, hampir setiap orang lebih memilih memainkan gawainya ketimbang bercakap-cakap langsung (Rizqi dan Pradana, 2018).

Memahami isu berkurangnya interaksi tatap muka setelah hadirnya teknologi seperti hasil penelitian yang dilakukan oleh Rizqi dan Pradana di atas, jauh sebelum itu Haring telah memaparkan dampak negatif dari internet. Menurut Haring, tentang dampak negatif internet dalam kehidupan sosial yang menyatakan bahwa "waktu tiga atau empat jam habis di depan komputer tetapi tidak dengan keluarga, suami atau istri, atau masyarakat" (Severin, 2014). Kehadiran teknologi mengurangi kualitas interaksi antar manusia, jadi jarang berkomunikasi face to face dan sibuk dengan PC, laptop, gawai. Realita yang terjadi saat ini, meskipun milenial dan gen $\mathrm{Z}$ terlihat duduk bersama di suatu tempat (kafe, ruang publik, dan lain-lain), mereka sibuk dengan gawainya sendiri-sendiri dan bermain media sosial dan gaming. Mereka tetap sibuk dengan aktivitas di dunia maya, stalking (mencari tahu) beragam konten yang diminati sesuai kebutuhan pribadi, dan melihat informasi tentang diri orang lain lewat status.

Peneliti mengamati isu perubahan perilaku komunikasi milenial dan gen $\mathrm{Z}$ tidak sedang baik-baik saja. Melihat realita yang ada di lapangan, semacam ada gangguan komunikasi yang bisa menghilangkan dari makna komunikasi itu sendiri. Komunikator yang terabaikan, dapat merasa kecewa atau marah saat berinteraksi dengan komunikan yang tetap asyik dengan kegiatan digitalnya. Maka dari itu ada potensi negatif bila pesan disalahartikan atau tidak mendapat respons (Tubbs \& Moss, 2012). Sejatinya harus ada etika penggunaan digital saat sedang berkomunikasi dengan orang lain, apa saja yang harus dilakukan. Literasi perilaku komunikasi yang baik menggunakan gawai, perlu diberikan kepada milenial dan gen $\mathrm{Z}$ di lingkungan sosial. Harusnya ada batasan waktu penggunaan gawai ketika ada lawan bicara mengajak berinteraksi gawainya dapat disimpan terlebih dahulu utnuk menghormati lawan bicara. Perubahan perilaku komunikasi berkomunikasi dengan orang yang lebih tua, sekarang juga menjadi berubah. Budaya sopan santun berkomunikasi di Ranah Minang, khususnya di Kota Padang dahulunya ketika orang-orang yang lebih tua berbicara, diperhatikan dengan saksama menunjukkan rasa hormat dengan menatap wajah lawan bicara juga berkaitan pada perilaku manusia. Namun saat ini, faktanya orang tua yang berbicara kepada anakanaknya, dijawab dengan respons yang lambat tanpa melihat wajah orang tua, dan tetap memainkan gawai mereka. Fakta tersebut berasal dari observasi yang peneliti lakukan terhadap informan di wilayah Kuranji.

Interaksi nyata begitu dirindukan karena di mana pun melihat orang era digital ini lebih asyik bermain gawai yang mereka genggam dan memilih berinteraksi dengan orang yang jauh di belahan dunia lain menggunakan media sosial. Kadang mereka tertawa sendiri melihat konten di media sosial, terkadang sampai ada nuansa sedih dan terpana melihat status-status dari teman, 
rekan kerja yang mengunggah keunggulan diri mereka beserta sederetan kesenangan lainnya di media sosial. Hal ini senada dengan tulisan Prof. Nursyirwan Effendi yang dimuat oleh surat kabar Padang Ekspres pada Selasa, 05 November 2019 bahwa komunikasi berbasis teknologi telah mengubah konektivitas sosial (Effendi, 2019).

Kehidupan ala Industri 4.0, suka atau tidak suka telah mengubah konektivitas sosial. Produk-produk komunikasi berbasis teknologi Artificial intelligence digital dan jejaring siber telah mengubah konektivitas sosial, ekonomi politik, budaya dari berhadapan (face-to-face) dan membentuk pola tatap kata-kata dan gambar. Akibat pada aspek sosial pun terjadi, perspektif tentang interaksi manusia dianggapnya sebenar-benarnya ada bila langsung secara maya (virtual) dan nirkabel (wireless connectivity).

Perubahan itu perlahan menggerus budaya sosial, sebab kehadiran teknologi komunikasi berbasis artificial intelligence. Perubahan yang tampak adalah perilaku yang tidak interaktif dalam berkomunikasi tatap muka di wilayah Kuranji, Kota Padang. Fenomena komunikasi pun menjadi berubah dari semula tatap muka, sekarang tren dengan dunia maya (virtual). Dua dunia yang berbeda, bahkan dunia nyata sesungguhnya bisa dimanipulasi oleh dunia maya dengan sederetan aplikasi-aplikasi canggih. Citra personal seorang punya potensi besar dimanipulasi pada era digital.

Idealnya, saat berkomunikasi tatap muka adalah saling memerhatikan lawan bicara, agar tidak kehilangan makna arah pesan yang disampaikan oleh komunikator. Karena akan ada rasa saling menghargai antara komunikator dengan komunikan saling peduli terhadap pesan-pesan yang disampaikan, sehingga tidak terjadi kesalahpahaman komunikasi terhadap pesan yang disampaikan dan pesan yang diterima. Milenial dan gen $\mathrm{Z}$, punya cara berbeda untuk merespons digital, maksudunya adalah saat penggunaan perangkat digital, Gen $\mathrm{Z}$ lebih multitasking dibandingkan milenial. Berdasarkan pengamatan, gen $\mathrm{Z}$ lebih cepat merespons perangkat digital dibandingkan milenial. Tanpa belajar dan diajari pun, gen $\mathrm{Z}$ bisa memainkannya. Berbagai macam kegunaan gawai bagi milenial dan gen $\mathrm{Z}$ tidak hanya untuk berhubungan memenuhi kebutuhan komunikasi, tetapi juga sudah menjadi sarana informasi, edukasi, hiburan dan sebagainya.

Seharusnya komunikasi secara langsung dapat berjalan dengan lancar ketika dua orang bertemu dan duduk secara berdekatan. Faktanya komunikasi secara langsung tidak berjalan dengan lancar sehingga terjadinya banyak kesalahpahaman dalam pemaknaan terhadap apa yang telah disampaikan komunikator (penyampai pesan) kepada komunikan (penerima pesan) saat sibuk bermain gawai. Berbeda dengan komunikasi yang ada pada dunia maya, komunikasi dengan orang yang berjauhan dalam percakapan online lebih cepat direspons dan dianggap lebih menarik.

Tulisan ini bertujuan menyajikan fenomena perubahan perilaku berkomunikasi milenial dan gen $\mathrm{Z}$ saat pengguna gawai melakukan komunikasi menjadi jarang tatap muka ketika mereka bertemu secara fisik, tetapi tidak melakukan komunikasi tatap muka (face-to-face) yang baik dengan saling menghargai lawan bicara. Secara sadar, peneliti terlibat dalam dinamika kehidupan sebagaimana internet hadir sebagai kebutuhan.

Banyak hal yang terjadi setelah kehadiran gawai dan media baru dalam ranah sosial, berbagai macam perubahan perilaku komunikasi milenial dan gen $\mathrm{Z}$ yang tidak bisa diprediksi dalam mengekspersikan ungkapan-ungkapan perasaan mereka dalam dunia maya. Apakah dunia nyata akan tenggelam dengan tren hidup di dunia maya, bahkan dalam acara makan malam bersama keluarga yang sedang berlangsung. Menurut observasi di lapangan, mengamati milenial dan gen $\mathrm{Z}$ masih sempat memainkan gawai mereka menunjukkan adanya penggunaan pada dua dunia berbeda, nyata dan maya. Mereka 
membagi waktu dan porsi pikirannya sehingga terjadi ketidakseimbangan fokus kepada pertanyaan-pertanyaan yang dilontarkan oleh komunikator kepada orang yang sedang asyik memainkan gawai. Tulisan ini bertujuan untuk memberikan pandangan alternatif tentang perspektif terjadi perubahan perilaku komunikasi face to face yang berlangsung. Peneliti bertujuan mendeskripsikan bagaimana terjadinya perubahan perilaku berkomunikasi yang terjadi di kalangan milenial dan gen $\mathrm{Z}$.

Fenomena perubahan perilaku komunikasi milenial dan gen $\mathrm{Z}$ menjadi penting untuk diteliti, sebab terkait dengan perubahan perilaku komunikasi yang mengantarkan kepada arah baru perubahan perilaku dalam berkomunikasi secara langsung. Apakah tidak ada yang merindukan interaksi secara nyata/alamiah, dampak dari keberlanjutan fenomena sibuk dengan gawai sendiri-sendiri berujung lahirnya antipati dalam kehidupan sosial, dan kurangnya rasa saling menghargai.

Berangkat dari fenomena perubahan perilaku komunikasi milenial dan gen $\mathrm{Z}$, penelitian ini difokuskan pada dinamika komunikasi, khususnya perubahan perilaku berkomunikasi face to face milenial dan gen $\mathrm{Z}$ yang erat kaitannya dengan teknologi. Penelitian ini juga bertujuan untuk mendeskripsikan fenomena perubahan perilaku komunikasi milenial dan gen $\mathrm{Z}$ pada era digital berkomunikasi dalam kehidupan sehari-hari di Kecamatan Kuranji. Sebagai bahan karya ilmiah, penelitian ini bermanfaat jangka panjang untuk Pemerintah Kota Padang dan kota/kabupaten di Indonesia dalam mengalami permasalahan perubahan perilaku komunikasi yang sama pada milenial dan gen $\mathrm{Z}$ dalam pembuatan kebijakan.

Terdapat beberapa kerangka teori yang digunakan, yaitu perilaku atau tingkah laku adalah kebiasaan bertindak yang menunjukkan tabiat seseorang yang terdiri dari pola-pola tingkah laku yang digunakan oleh individu dalam melakukan kegiatannya (Nur, 2017). Perilaku menekankan kebiasaan berdasarkan pengalaman hidup yang ditemui masing-masing individu yang dipengaruhi oleh faktor lingkungan sekitar. Komunikasi merupakan bagian penting bagi manusia dalam kehidupan sehari-hari, seperti yang dituangkan dalam (Mulyana, 2013) we cannot not communicate.

Ungkapan tersebut bermakna kita tidak dapat tidak berkomunikasi. Mulyana menempatkan prinsip bahwa setiap perilaku mempunyai potensi komunikasi. Alih-alih, komunikasi terjadi bila seseorang memberi makna pada perilaku orang lain atau perilakunya (Mulyana, 2013). Tentu saja perilaku komunikasi berkaitan dengan interaksi yang terjadi antar manusia, pandangan komunikasi sebagai interaksi menyetarakan komunikasi dengan proses sebab-akibat atau aksi-reaksi, yang arahnya bergantian.

Kedua, teori yang yang digunakan adalah komunikasi interpersonal, Komunikasi interpersonal menurut Devito adalah penyampaian pesan oleh satu orang dan penerimaan pesan oleh orang lain atau sekelompok kecil orang, dengan berbagai dampaknya dan dengan peluang untuk memberikan umpan balik segera (Aw, 2011). Pesan disampaikan oleh komunikator (penyampai pesan) kepada komunikan (penerima pesan) dengan adanya umpan balik yang diterima oleh komunikan. Komunikasi interpersonal biasa digunakan dalam kehidupan sehari-hari oleh manusia, baik kepada keluarga, rekan kerja, maupun masyarakat umum.

Ketiga, teori yang yang digunakan adalah komunikasi generasi milenial. Generasi milenial merupakan adalah generasi modern yang hidup di pertengahan milenium. Secara bersamaan pada era digital ini mulai merasuk ke sendi-sendi kehidupan (Hidayatullah, Devianty, \& Wibowo, 2018).

Keempat, teori yang yang digunakan adalah komunikasi generasi Z. Generasi Z adalah generasi yang lahir individu yang lahir setelah 1995. Penelitian Bencsik, Csikos, \& Juhez menunjukkan masuknya di dalam kelompok yang lahir dari tahun 19952010 (Putra, 2016). Generasi yang paling 
muda dalam angkatan kerja adalah generasi $\mathrm{Z}$, disebut juga iGeneration atau generasi internet. Generasi $\mathrm{Z}$ memiliki kesamaan dengan generasi milenial, tapi generasi $\mathrm{Z}$ mampu mengaplikasikan kegiatan dalam satu waktu (multi tasking) seperti menjalankan media sosial, menggunakan gawai, browsing, mendengarkan musik menggunakan headset (Putra, 2016).

Kelima, new media telah digunakan sejak tahun 1960-an dan telah mencakup seperangkat teknologi komunikasi terapan yang semakin berkembang dan beragam (Mcquail, 2011). Komunikasi massa tradisional pada intinya bersifat satu arah, sementara bentuk baru komunikasi secara pokok adalah interaktif (Mcquail, 2011). Perbedaan mendasar tersebut yang mengantarkan kepada proses berpikir bahwa media baru punya kekuatan interaktif yang bisa memberikan respon kepada orang yang memberikan opini tentang suatu hal. Pada media baru, siapa pun yang terhubung ke jaringan internet dapat membuat konten yang mereka inginkan.

Keenam, behaviorisme sosial merupakan teori yang digagas oleh George Herbert Mead yang merujuk pada perilaku manusia yang khas. Teori behaviorisme sosial merupakan pengembangan dari teori behaviorisme, yakni teori belajar yang lebih menekankan pada tingkah laku manusia. Teori ini memandang individu sebagai makhluk reaktif yang memberi respon terhadap lingkungan (Daryanto, 2016).

Urgensi dari penelitian ini adalah mendeskripsikan dinamika pengguna gawai yang kecanduan, korban internet, orang tua, dan pemerintah dalam penguatan jati diri milenial dan gen $\mathrm{Z}$ mengantisipasi dari kehidupan antisosial.

Penelitian ini bermanfaat secara akademis karena diharapkan dapat memberikan masukan dalam bidang ilmu komunikasi, khususnya pada teori bahwa komunikasi milenial era 4.0 dan melihat perilaku komunikasi milenial dan gen $\mathrm{Z}$ setelah kehadiran teknologi. Hasil temuan penelitian ini diharapkan dapat memberikan kontribusi pada penelitian selanjutnya mengenai komunikasi sosial yang melihat sektor komunikasi interpersonal milenial dan gen $\mathrm{Z}$, serta dampak kehadiran teknologi yang mengubah cara berkomunikasi.

Secara praktis, hasil penelitian ini diharapkan dapat memberikan masukan secara langsung sebagai bahan pertimbangan bagi orang tua, guru, dosen, dan tokoh dalam memberikan sentuhan kepada milenial dan gen $\mathrm{Z}$ untuk tetap menjaga perilaku komunikasi yang efektif serta menjaga etika dalam berkomunikasi dengan berbagai pihak di ranah publik. Penelitian ini juga memberikan rekomendasi yang tepat untuk pribadi-pribadi yang kecanduan terhadap gawai sehingga menghilangkan rasa kemanusiaan dalam kehidupan sosial. Sudah saatnya kembali memanusiakan manusia.

Penelitian ini juga memberikan manfaat pada orang tua milenial dan gen $\mathrm{Z}$ sebagai panduan dalam memberikan gawai kepada anak pada waktu yang tepat agar tidak terjadi kesalahangunaan dalam pemakaian. Selain itu, hasil penelitian ini diharapkan dapat digunakan sebagai bahan evaluasi pemerintah Kota Padang terkait pengembangan program yang tepat digunakan untuk milenial dan gen $\mathrm{Z}$ dalam menjaga komunikasi di dunia nyata menjadi seimbang. Begitu juga dapat digunakan oleh pemerintah kota/kabupaten yang membutuhkan karya ilmiah ini untuk pembuatan kebijakan program milenial dan gen $\mathrm{Z}$ kembali berinteraksi tatap muka.

\section{Metode}

Penelitian ini menggunakan metode penelitian kualitatif, Menurut Strauss dan Corbin mendefinisikan metode penelitian kualitatif sebagai "jenis penelitian yang temuan-temuannya tidak diperoleh melalui prosedur statistik dan bentuk hitungan lainnya" (Afrizal, 2017). Secara sederhana, dipahami bahwa penelitian kualitatif bersifat mendeskripsikan, menganalisis suatu fenomena atau kasus.

Penelitian ini menggunakan pendekatan fenomenologi Alfred Schutz (1889-1959), 
yakni fenomenologi adalah menghubungkan antara pengetahuan ilmiah dengan pengalaman sehari-hari, dan dari kegiatan di mana pengalaman dan pengetahuan itu berasal. Peneliti melihat bagaimana pengalaman yang terjadi dalam perubahan perilaku komunikasi milenial dan gen $\mathrm{Z}$ dari sudut pandang informan. Pengalaman dan makna yang dapat diambil merupakan data yang peneliti dapatkan. Fenomenologi bertujuan untuk mengetahui dunia dari sudut pandang orang yang mengalaminya secara langsung atau berkaitan dengan sifat-sifat alami pengalaman manusia (Kuswarno, 2013).

Teknik pengumpulan data yang digunakan adalah wawancara mendalam, observasi, dan pengumpulan dokumen. Sumber data berupa hasil wawancara, temuan observasi di wilayah Kuranji, dan dokumen yang ada relevansinya. Teknik penentuan informan menggunakan purposive sampling, dalam penelitian ini adalah milenial dan gen $\mathrm{Z}$. Pada subjek penelitian ini, peneliti mewancarai subjek berdasarkan beberapa kriteria penelitian sebagai berikut:

1. Masyarakat yang berdomisili di Kecamatan Kuranji, Kota Padang.

2. Berusia 10- 39 tahun tergolong milenial dan gen $\mathrm{Z}$.

3. Pengguna gawai.

4. Pengguna media sosial, game online, dan aplikasi yang tersedia di Playstore dan Appstore.

Adapun untuk memperkuat penelitian, peneliti melakukan wawancara pada 10 informan, dokumentasi dengan melihat media, buku, jurnal yang membahas tentang komunikasi milenial dan gen $\mathrm{Z}$. Pada penelitan ini peneliti mengggunakan metode analisa data, Stevick-Colaizzi-Keen. Dilakukan dalam empat tahap. Pertama deskripsi lengkap yang dialami oleh informan, Kedua menelaah pernyataanpernyataan informan, ketiga telaah setiap informan, dan yang keempat membuat esensi dari fenomena yang dialami informan.
Untuk validitas data, Humphprey dalam Phenomenological Research Methods, mencontohkan teknik validasi data ini dengan mengirimkan hasil penelitian kepada masing-masing informan dan meminta mereka untuk mengoreksi atau memberikan masukan.

Penelitian dilakukan di Kecamatan Kuranji, Kota Padang, Padang yang dikenal sebagai ibu kota Provinsi Sumatera Barat. Kota Padang juga sebagai kota pendidikan sehingga banyak pendatang milenial dan gen $\mathrm{Z}$ yang berdomisili di sana untuk sekolah dan kuliah. Peneliti tertarik mengambil kota lokasi penelitian di Kecamatan Kuranji, Kota Padang, sebab banyak perilaku pengguna media sosial di Padang yang tidak fokus interaksi tatap langsung (face-to-face) berkomunikasi dalam ranah sosial setelah kehadiran era digital.

\section{Hasil dan Pembahasan}

\subsection{Perubahan Perilaku Milenial dan Gen $Z$ di Era Digital}

Perilaku merupakan perbuatan atau tindakan dan perkataan seseorang yang sifatnya dapat diamati, digambarkan dan dicatat oleh orang lain ataupun orang yang melakukannya (Arifin, 2015). Komunikasi merupakan suatu yang penting bagi manusia, bahkan kualitas hidup manusia ditentukan oleh pola komunikasi yang dilakukannya (Takariani, 2011).

Dahulu manusia lebih mengandalkan komunikasi tatap muka dalam menyampaikan pesan kepada komunikan dalam kehidupan sosial. Seiring berkembangnya teknologi internet begitu pesat, telah membawa perubahan interaksi komunikasi dan tatanan komunikasi antarmanusia, yang tadinya lebih mengandalkan komunikasi tatap muka kini bergeser ke arah penggunaan media khususnya internet (Takariani, 2011). Sebelum mengenal gawai, dahulu milenial dan gen $\mathrm{Z}$ dalam lingkungan sosial, lebih banyak mengandalkan komunikasi tatap muka dibandingkan menjalin interaksi di media sosial. Pengaruh perkembangan komunikasi, tidak terlepas dari 
perkembangan teknologi yang merupakan bagian dari komunikasi publik. Aspek terbesar dari teknologi adalah lahirnya era digital, di mana penggunaan teks dan dalam bentuk kode dapat terbagi dalam proses produksi, distribusi, dan penyimpanan dalam waktu bersamaan sekaligus (Syahputra, 2017).

Milenial dan Gen Z merupakan generasi yang akan menggantikan kepemimpinan di masa sekarang. Perubahan perilaku juga akan menentukan bagaimana arah perjalanan bangsa berikutnya. Terlebih dengan semakin antusias milenial dan Gen Z menggunakan media sosial. Pola interaksi yang bersifat banyak arah itulah yang mengakibatkan remaja antusias untuk menggeluti media sosial sebagai aktivitas interaksi sosial mereka sehari-hari (Triantoro, 2019).

Mengacu kepada pengalaman komunikasi milenial dan gen $\mathrm{Z}$ yang dikemukan kepada peneliti, memang ada perubahan-perubahan mendasar yang dirasakan secara oleh informan. Bahwa melihat kepada kebiasaan digital yang peneliti dapatkan dari sepuluh orang informan berasal dari milenial dan generasi Z. Kebiasaan digital adalah rekam jejak berapa lama penggunaan gawai yang digunakan informan dalam kurun waktu satu hari.

Paling rendah kedua generasi tersebut bermain gawai kisaran waktu empat jam sedangkan yang tertinggi sampai delapan belas jam. Angka tertinggi ini sangat fantastis, hampir lebih dari setengah hari dari salah satu informan bermain gawai sangat lama. Gawai saat ini menjadi kebutuhan dalam kebutuhan sehari-hari, semua informan mengakui membutuhkan gawai untuk aktivitas pendidikan, pekerjaan, hiburan dan bisnis. Kebutuhan untuk berbagi di lini massa media sosial.

Saat kita "share" kehidupan kita secara online, maka kita juga mendistribusikan materi digital tentang kehidupan kita kepada orang lain dan mengomunikasikan hidup kita kepada khalayak luas" (Adiarsi \& Silsa, 2018).
Berdasarkan hasil penelitian ini, perubahan perilaku komunikasi menjadi beberapa tema, berdasarkan pengalaman sepuluh orang informan. Fenomena perubahan perilaku komunikasi telah terjadi pada observasi dan wawancara mendalam. Pada awalnya, peneliti mendeskripsikan dan mengkategorikan perubahan perilaku komunikasi secara spesifik bagaimana perubahan perilaku yang terjadi pada generasi milenial dan juga begitu kepada gen $\mathrm{Z}$ secara khusus. Akan tetapi, setelah melakukan wawancara mendalam, ternyata ada kesamaan pengalaman dari kedua generasi milenial dan gen $\mathrm{Z}$ terkait pengalaman komunikasi yang dialami pada era digital.

\subsection{Proses Komunikasi dari Aktif Menjadi Pasif}

Komunikasi milenial dan gen $\mathrm{Z}$ sebelum mengenal gawai aktif dalam berkomunikasi, berubah menjadi pasif. Ketergantungan dengan gawai ini telah mengubah perilaku generasi milenial dalam berkomunikasi tatap muka yang sudah dirasakan oleh pengalaman informan Aah sebagai milenial adanya keterlambatan pesan yang disampaikan oleh komunikator kepada komunikan. Artinya, telah ada perubahan perilaku milenial dan gen $\mathrm{Z}$ menjadi pasif setelah hadirnya gawai.

"Ya kadang cepat, bisa respon langsung kadang ya kalau sedang serius dengan gawai ya agak terbaikan kalau orang bertanya. Bisa merespon dengan dipanggil satu kali dua kali, tergantung keseriusan melihat gawai. Kadang pertanyaan ditanya ulang kadang tidak."

Respon yang tidak bisa diprediksi tersebut karena lawan bicara sibuk atau fokus bermain gawai sehingga lawan bicara terabaikan. Komunikasi para informan gawai yang interaktif berubah menjadi pasif. Oleh karena itu, komunikasi antara dua orang terjadi dengan satu fokus gawai dan satu lagi mengajak berkomunikasi. Telah ada gawai sebagai hambatan, lawan bicara 
lebih fokus bermain gawai. Dengan demikian, respon dari lawan bicara menjadi delay, terkadang lawan bicara yang diajak berkomunikasi bertanya ulang apa pertanyaan yang sebelumnya telah dilontarkan.

Peneliti mengamati milenial dan gen $\mathrm{Z}$ berkomunikasi di berbagai tempat area penelitian dengan temannya sambil bermain gawai. Mereka tetap berkomunikasi secara nyata, tetapi sibuk melihat gawai masingmasing juga. Pengalaman dari Acen sebagai gen $\mathrm{Z}$ dalam berkomunikasi sebelum mengenal gawai lebih fokus dibandingkan saat ini.

"Lebih fokus, kalau sekarang kita ngobrol lawan bicara sibuk main gawai. Itu orangnya tidak mengerti dengan apa yang telah kita sampaikan ya kurang nyambung dan tidak konek" (Informan Acen)

Salah satu penyebab terjadinya perilaku komunikasi pasif ini disebabkan oleh lawan bicara sibuk main gawai. Era digital ini akses internet mudah dan cepat, perubahan perilaku penggunaan gawai pun berubah. Hal itu membuat orang terlena dan sibuk dengan gawainya masing-masing. Sesuai dengan keterangan yang diberikan Acen bahwa kalau dahulu berkomunikasi lebih fokus dibandingkan sekarang. Melihat aktivitas Gen $\mathrm{Z}$ saat ini super sibuk dengan gawainya tidak fokus dengan apa yang orang tanyakan, seperti peneliti berkomunikasi kepada Acen yang sedang asyik bermain gawai dan tidak menyimak atau tidak menghiraukan posisi peneliti yang berada di sampingnya. Sebaliknya, jika peneliti sibuk bermain gawai, disapa oleh Acen peneliti juga tidak fokus berkomunikasi dengan Acen.

Istilahnya saat ini kalau mau orang lain mendengarkan kita ya silahkan berbicara tanpa diperhatikan dengan saksama., Kita bicara sendiri orang lain yang katanya sebagai pendengar juga sibuk dengan gawainya. Pengalaman seperti ini sering peneliti temui saat bersama Acen jika sedang terlalu fokus bahkan lupa ada kita yang sedang butuh bicara.

Menurut hasil penelitian yang dilakukan oleh Saleh dan Pitriani bahwa media sosial Instagram dan Whatsapp mengandung pengaruh dalam pembentukan budaya alone together di Universitas Riau (Saleh \& Pitriani, 2018). Budaya alone together merupakan kondisi beberapa orang atau sekolompok kumpul bersama, tetapi asyik dengan gawai masing-masing.

Pengalaman informan Abdul sebagai Milenial mengungkap merasa ada kepuasan berteman baik itu untuk cerita dan bermain bersama. Memang godaan gawai selalu di saat kumpul bersama dan melihat mana yang prioritas.

"Sebelum menggunakan gawai rasanya berbeda banget rasanya. Contohnya sebelum mendapatkan gawai saya ketika kumpul bersama kawan-kawan puas kita berteman, cerita puas, ketika saya sudah ada gawai ya susah ketika berkumpul itu kawan-kawan sibuk dengan gawainya. Contohnya saja janjian kumpul yang datang empat orang, tidak banyak waktunya untuk saling bicara termasuk saya. Kebanyakan sibuk dengan gawainya masing-masing, itu yang saya rasakan. Biasanya saya ngumpul di warung kopi seperti ini, kadang berkunjung ke kos kawan, kadang kumpul ke rumah kawan. Tapi ada sebagian kawan yang dia ketika kumpul bersama teman lebih baik gawainya ditinggalkan, masih ada bang pernah saya tanyakan ke dia, kenapa meninggalkan gawai? Jawabnya agar fokus kumpul dengan teman-teman fokus juga, cerita dengan teman-teman tidak ada yang mengganggu. Kalau saya pribadi kemana pun pasti membawa gawai. Tidak pernah saya tinggalkan, kadang saya sedang kumpul ada juga yang telfon. Kalau seandainya penting banget seperti pacar, orang tua, diproritaskan menjawabnya dahulu."

Kondisi berbeda zaman dahulu sebelum mengenal gawai, Abdul lebih puas 
berkomunikasi dengan temannya. Keluh kesah dengan keadaan yang disampaikan oleh informan juga terjadi pada dirinya sendiri saat orang lain bicara Ia sibuk bemain gawai atautelfon pacarnya. Perubahan dalam frekuensi.

Perkembangan teknologi telah menyebabkan berkurangnya frekuensi individu untuk saling bertatap muka. Semua kebutuhan untuk berinteraksi dapat dipenuhi dengan memanfaatkan teknologi. Seorang nasabah bank tidak perlu berulang kali bertemu dengan petugas teller bank. Fungsi dan peran teller bank telah tergantikan oleh mesin ATM (Automatic Teller Machine atau Anjungan Tunai Mandiri) yang mampu melayani nasabah selama 24 jam di mana saja, tanpa harus mengantri lama, atau menulis formulir tertentu (Ngafifi, 2014).

\subsection{Berkurangnya Komunikasi Tatap Muka}

Kehadiran gawai juga melahirkan budaya tidak acuh dengan lingkungan sekitar sehingga berkurangnya komunikasi tatap muka. Informan Acen juga membandingkan komunikasi tatap muka dengan orang lain. Pengalaman pribadinya yang juga berkomunikasi dengan orang yang seumurannya ada tidak menyambung saat berkomunikasi saat satu di antara yang hadir tidak memperhatikan lawan bicara.

"Lebih bagus komunikasi, apa yang kita sampaikan itu lebih ditangkap oleh lawan bicara. Dahulu berkomunikasi dengan teman-teman lebih intim dan konek istilahnya. Tidak ada yang mengatakan apa tadi ? apa? Apa? Apa tadi?, tidak ada yang seperti itu."

Jika dahulu Acen merasakan adanya intim berkomunikasi, saat ini dengan lingkungan sebayanya sudah mulai tidak fokus dengan sering mengatakan apa tadi ? apa? Apa? Apa tadi?, ulang lagi saya tadi sedang lihat situs ini. Perubahan ini terjadi karena fokus sudah terbelah antara mansuia dan benda (gawai).
Fenomena perubahan perilaku komunikasi dengan teman, sanak saudara, berkomunikasi sambil memegang gawai "dia ngobrol sama kita, tapi mereka pegang gawai dan chating terus juga. Terus bercabanglah pikiran dia" ungkap Acen. Berdasarkan pengalaman tersebut, bahwa benar adanya fenomena yang pernah peneliti uraikan pada latar belakang masalah. Masalah tersebut tidak hanya terjadi di lingkungan keluarga, tetapi juga di ruang publik seperti cafe misalnya.

Perilaku gen $\mathrm{Z}$ menjadi tidak acuh dengan kehidupan sekitar, tetapi hanya peduli dengan gawainya masing-masing. Perubahan perilaku komunikasi yang tidak peduli dengan komunikator ini membahayakan kepada penerimaan pesan yang diterima dan kemungkinan kesalahpahaman juga berpeluang besar. Bahwa dengan tidak saling peduli antara komunikator dan komunikan dapat menimbulkan korban dari kesalahan penerimaan pesan. Di samping itu, hal tersebut dapat dilihat dari sudut pandang lawan bicara yang sibuk dengan gawainya sendiri saat ada teman ngobrol.

Melihat aktivitas sehari-hari menggunakan gawai. Ada pada waktu tertentu sedang berbicara terus bermain gawai, apa saja aktivitasnya?

"Palingan scroll-scroll instagram saja,
intinya bukan tidak fokus ke dia Cuma
mencari tempat melihat saja begitu. Bukan
fokus ke gawainya, tetap fokus ke
orangnya dengerin orangnya Cuma tidak
mau kontak mata saja. Tidak nyamanyan
saja, saya saja sebenarnya tidak nyaman
kontak-kontak mata sama orang. Tetap saja
fokus sama orangya dalam berinteraksi
Cuma sering matanya tidak nyaman kontak
mata samarang."

Bagi informan, melihat ke gawai adalah salah satu cara agar tidak terlalu melihat mata lawan bicara, tetapi fokusnya tetap kepada apa yang dibahas. Pada kenyataannya, jika orang melihat ke arah lain tentu hal tersebut juga tidak menghargai orang yang sedang berbicara. Menurut pengalaman informan, sebelum kehadiran gawai komunikasi tatap 
mukanya lebih berkualitas. Sebelum mengenal gawai, tatap muka tidak ketika berbicara dengan lawan bicara? "Lebih berkualitas dahulu lah, karena dahulu bisa dikatakan tidak ada pelampiasan itu lagi. Tidak ada gawai itu, gawai itu ya berarti kita harus melihat orangnya tidak ada yang bakal kita pegang". Bagaimana jika diajak komunikasi apakah direspon? "Siap siaga kok" ungkap informan.

Akan tetapi, bagaimana pun alasan yang diungkapkan oleh informan di atas bahwa bermain gawai hanya sebagai tempat pengalihan mata. Orang yang melihat akan berpikiran informan sudah masuk ke dalam ranah tidak acuh dengan kehidupan sosial atau tidak peduli dengan lingkungan sekitar.

Artinya, gawai punya pengaruh signifikan terhadap perilaku milenial dan gen $\mathrm{Z}$ sehingga, mengurangi komunikasi tatap muka. Jika ada perintah dari orang tua, juga tidak dikerjakan secara cepat.

"Pengaruh gawai ini kan emang iya banyak pengaruh negatifnya bagi anak muda. Pertama, membuat malas, apa saja malas dikerjain contohnya disuruh orang tua susah banget, sosialisasi saya itu yang pertama. Berpengaruhlah ke sosialnya, rasa menghargai orang itu sudah jelas kurang." (Informan Jamal)

Karena berkomunikasi tatap muka tidak berjalan ideal, maka timbul perilaku yang tidak saling menghargai karena sibuk bermain gawai.

\subsection{Tidak Fokus dalam Berkomunikasi}

Tidak fokus dalam berkomunikasi dapat menyebabkan diskomunikasi. Informasi yang disampaikan tidak seutuhnya diterima oleh komunikan. Bermain gawai merupakan hambatan dalam proses komunikasi interpersonal antara satu orang dengan orang lainnya. Hambatan ini merupakan temuan peneliti berdasarkan observasi dan wawancara mendalam dari informaninforman mengungkapkan tidak fokus dalam berkomunikasi, pengalaman informan ini berasal dari milenial dan gen $\mathrm{Z}$ yang menceritakan ketika mereka di posisi sebagai bagian dari komunikator mengungkapkan kekesalan kepada orang yang fokus mendengar apa yang disampaikan. Pada posisi lain, saat orang mengajak informan berkomunikasi, ia malah sibuk bermain gawai tidak memikirkan bagaimana perasaan lawan bicara. Komunikator dan komunikan dalam membahas satu hal menjadi tidak jelas topik pembahasannya dan terkadang komunikan tidak menjawab pertanyaan dari komunikator. Dalam berkomunikasi, perilaku milenial dan gen $\mathrm{Z}$ tidak fokus memerhatikan apa yang disampaikan oleh komunikator. Perubahan perilaku komunikasi bisa satu waktu terjadi yang dipengaruhi oleh situasi dan lingkungan sekitar. Perkembangan digital membuat perubahan perilaku juga terjadi pada Albert, lewat pengalaman pribadinya bahwa ia merasakan perubahan perilaku komunikasi yang terjadi.

"Kalau dulu sebelum mengenal Gadget duduk nongkrong sama teman-teman itu lebih berasa, bahasa minangnya cerita lamanya lamak bana. Semenjak kenal dengan gawai, duduk nongkrong sama teman-teman itu sibuk main game, ada yan main hp. Masing-masing fokus ke hp sendiri tanpa memikirkan teman sebelahnya."

Jika dahulu sebelum mengenal gawai, intensitas komunikasi antara satu orang dengan yang lainnya saat bersamaan lebih kuat. Banyak cerita yang bisa disampaikan dan cerita itu dipahami oleh anggota yang ikut berdiskusi di sebuah tempat. Realitanya pada saat ini sudah bisa disaksikan di mana saja terlihat orang kumpul-kumpul bersama sibuk memainkan gawainya masing-masing. Seperti yang terjadi juga pada Albert bahwa dirinya merasakan adanya sensasi zaman sebelum mengenal gawai ada rasa berteman. Pada masa teman-temannya sudah mengenal gawai termasuk dirinya, sibuk juga bermain gawai masing-masing, teman yang sebelah sibuk dengan urusannya, Albert juga sibuk dengan urusan pribadinya. Pada saat 
bersama peneliti dengan Albert juga mempraktikkan demikian, Albert sibuk dengan gawainya peneliti juga sibuk dengan gawai sendiri.

Fenomena yang terjadi perubahan perilaku komunikasi tidak fokus ini terjadi karena kesibukan dari salah seorang dalam unsur komunikasi yang bermain gawai. Bahkan, komunikasi tatap muka juga tidak terjadi lagi seperti zaman sebelum ada gawai oborolan serius tidak serius memerhatikan wajah atau kening lawan bicara. Komunikasi tatap muka ini juga tergantung pribadi orang, situasi dan topik pembahasan. "Kalau serius, ya, mereka letakkan gawainya, terus mereka menatap kita kebanyakan. Kalau obrolan tidak serius, ya, sambil-sambil melihat gawai." Memang sudah zaman telah berubah. Gen $\mathrm{Z}$ juga sekarang sudah memaklumi orang yang ketika diajak mengobrol tidak mendengarkannya. "Udah zamannya juga seperti ini sekarang". Ungkapan Acen demikian menunjukkan bahwa zaman sudah berubah dan cara orang hidup pun mulai berubah. Senada dengan Laila. Sebagai orang yang terlibat dalam praktik dunia digital saat ini, informan tidak ada yang merasakan kesal dan sudah memaklumi kalau bisa multitasking untuk mengerjakan yang lain kenapa tidak.Informan sering tidak fokus mendengarkan yang disampaikan oleh teman saat berkumpul dan sibuk dengan urusan pribadi.

"Kalau tidak fokus dengan obrolan orang, sepertinya saya sering, deh. Ungkap Laila. Tapi saya tetap rekam apa yang dia bilang, kadang sisi lainya saya multitasking otaknya ke mana, pikirannya ke mana, telinganya ke mana, tetapi sering juga ketemu sama orang yang sibuk main gawai kita sudah ngobrol panjang lebar ternyata dia $h a$ apa tadi? Itu yang tidak saya suka.” (Informan Syaiful)

Sementara itu, Arfan yang juga sebagai gen $\mathrm{Z}$ menyatakan mereka yang sibuk dengan gawai saat komunikasi tatap muka sedang berlangsung sehingga tidak fokus menyediakan beberapa waktu untuk berkomunikasi tatap muka lebih khidmat.

"Miris, lah, seperti tidak ada waktu.Oke orang itu sibuk dengan hal penting. Cuma tidak 12 jam atau 24 jam sibuk, kan. Ngumpul itu cuma sesekali beberapa jam cuma.Masa, iya, menyediakan waktu 2-3 jam untuk nongkrong tidak bisa”

Dalam berinteraksi, diperlukan saling mendengarkan satu dengan yang lainnya untuk komunikasi efektif. Kemampuan komunikasi merupakan salah satu ciri-ciri keterampilan sosial. Seseorang yang memiliki kemampuan mendengar secara responsif akan dapat merespon pesan dari orang lain secara proporsional, disesuaikan dengan situasi dan kondisi komunikan (Aswar, 2020).

Perangkat teknologi telah berhasil memengaruhi perilaku penggunanya dengan membuat orang dapat bertahan lama di layar gawai. Teknologi bisa menghadirkan dua dunia yang berbeda. Hal ini senada dengan pernyataan Roeslin. Menurut Roselin (Ekasari \& Dharmawan, 2012), perkembangan teknologi internet juga tidak saja mampu menciptakan masyarakat dunia global saat ini, namun mampu menciptakan suatu transformasi dalam ruang gerak kehidupan baru bagi masyarakat, sehingga tanpa disadari manusia telah hidup dalam dua kehidupan yaitu kehidupan masyarakat nyata dan kehidupan masyarakat maya (cyber community).

Alasan adanya dua kehidupan ini membuat banyak Milenial dan Gen Z di wilayah Kuranji terlena dengan gawainya. Pola perilaku yang disiapkan era digital ini perilaku yang terjadi saat berkomunikasi interpersonal dengan tidak memerhatikan lawan bicara. Ada media yang membuat milenial dan gen $\mathrm{Z}$ terus multitasking antara sedang bicara dan melakukan aktivitas lainnya di dunia maya. Respon dari komunikan tidak sebaik sebelum era digital yang langsung saling pengertian dan memerhatikan lawan bicara. 


\subsection{Perilaku Komunikasi Daring}

Perilaku virtual sebagaimana individuindividu yang tergabung menjadi satu kelompok masyarakat, perilaku sekelompok individu dimaksud dapat diamati melalui media komunikasi virtual seperti contoh antara lain melalui media sosial dan website (Wicaksono \& Irwansyah, 2017). Perilaku tersebut juga dapat diamati melalui media sosial pribadi informan, bagaimana riwayat perilakunya dalam menggunakan media.

Saat peneliti bertanya lebih nyaman interkasi tatap muka atau online? Salah satu Informan menjawab "Lebih di gawai sepertinya". Kenyataan kenyamanan berinterkasi di gawai menyapa orang dibandingkan menyapa tatap muka, temuan ini merupakan dinamika komunikasi online yang terjaadi saat ini. Selama menggunakan media sosial, barangkali ada informan berkenalan di media sosial dan ternyata juga pernah melakukan perilaku menyimpang.

"Pernah, itu penyimpangan sosial. Penyimpangan apa jadinya itu, ya. Karena sudah menikah, kan. Jadi ada seseorang yang spesial lah muncul di media sosial. Pengalamannya kalau kita udah menikah, ini kan kadang kurang perhatian kita dari pasangan. Jadi masuklah orang yang bisa perhatian kita begitu. A itu yang penyimpangannya kan, untuk saat kini tidak berlanjut. Itu hanya berlangsung sekitar tiga bulan. Udah tiga bulan itu, mangkanya baru tahu, pastilah dia marah. Keluarga yang tahu waktu itu cuma ibu."

Perilaku menyimpang di dunia online muncul sesuai pengalaman yang disampaikan pengalaman informan wanita yang sudah menikah. Disebabkan tidak mendapat perhatian dari suami, informan mencari perhatian dari pria lain yang juga seumuran. Interakasi jarak jauh membuat informan dengan orang baru yang masuk berjalan selama tiga bulan. Penyimpangan ini bisa saja terjadi karena sudah candu bermain online dan mendapatkan perhatian lebih. Namun dengan ketahuan oleh suami, permasalahan tersebut diselesaikan degan baik-baik antara kedua pasangan suami istri tersebut kembali damai dan pihak yang berkenalan lewat dunia online putus kontak.

Komunikasi online bukan berarti hanya sekadar komunikasi saat ini, tapi juga sebagai sumber konflik. Karena kata yang disampaikan, bisa saja disampaikan secara frontal sehingga disalahartikan oleh para pembaca. Misalnya pengalaman Abdul, konflik dengan temannya di grup.

Informan saat bermasalah dengan satu orang dalam interaksi online akan berpengaruh kepada teman yang lain. Pernah konflik di media sosial dengan teman?

"Jarang, Bang. Ketika ada orang yang masuk ranah saya, misalnya dia terlalu apa dengan privasi saya begitu, kan. Dulu kan awal-awal pacaran sering upload foto berdua dengan pacar. Ketika itu, kawan saya yang memasukkan foto saya ke group sekolah lah dulu kan. Ketika itulah, saya pernah konflik dengan teman, saya tidak suka begitu. Konteksnya kan saya foto berdua dengan mantan saya kan, dia masukkan ini bagaimana ini, nih? Dia minta pendapat ke kawan-kawan di dalam grup itu tentang foto saya berdua. Jadi, saya marah dan keluar dari grup. Saya chat pribadi orang itu, saya carut marut, itulah saya pernah konflik untuk di media sosial. Saya blokir dia di semua media sosial" (Informan Abdul)

Dalam permasalahan tersebut, di dunia online grup whatsapp ada yang menghakimi informan dan mengumumkan di grup alumni bahwa informan dengan pacarnya sedang mesra. Tidak terima diperlakukan demikian, akhirnya informan marah dan memblokir semua akses media sosialnya dan ujung dari permasalahan Ia juga bermasalah terlibat dengan teman lainnya dan kemudian menghilang beberapa tahun.

Peneliti juga melihat bagian interaksinya dengan teman online-nya. Informan Mila suka berinteraksi di Instagram "Karena disana itu interaksi juga luas, tidak dalam negeri." Interaksi online 
memang cukup unik, apa yang dialami oleh informan adalah kalau chatting itu ditanggapi secepat mungkin, tetapi tidak pada respons orang yang bertanya secara langsung atau tatap muka. Perasaan akrab pun timbul ketika di chatting, tetapi saat bertemu secara langsung malah kaku.

"Misalnya, kalau memang Mila lagi butuh dan kalau ada teman yang nge-chat Mila secepat mungkin Insyaallah ditanggapi. Media sosial itu mendekatkan yang jauh dan menjauhkan yang dekat. Kadang ketika bermedia sosial, chat begitu kan memang terasanya akrab banget. Karena setiap orang yang aslinya pendiam ketika di chat itu receh banget, tapi ketika ketemu kebalikan. Kalau pengalaman di media sosial tidak menjamin seperti apa keadaan orang itu".

Memang orang yang di media sosial itu belum jaminan bagaimana perilakunya di dunia nyata sama. Tentu ada pernah membohongi juga di media sosial?, walaupun niat awalnya bukan berbohong. "Dalam tanggapan biasa-biasa saja emang Mila tanggap biasa saja, sebenarnya Mila lagi tidak pengen chat-an. Kalau di chat, biasanya ketika hahaha Mila tidak tertawa tapi senyum saja"

Artinya, ada kepalsuan dalam chating yang sebenarnya kita tidak sedang bahagia, dibuat seolah bahagia kesan yang dibaca dari chat yang dikirim sehingga muncullah perilaku tidak jujur. Pada sisi lain, ada juga yang asyik dengan media sosial saat berkumpul. Biasanya Gen Z suka duduk, nongkrong di kafé termasuk informan suka bertemu teman di kafé dan pamer di media sosialnya. Akan tetapi, perilaku bermain gawai sambil mengobrol itu tetap ada, padahal sebelumnya janjian untuk cerita, ya, ujungnya untuk keperluan instastory juga kemudian teman yang hadir di-tag.

"Biasanya nongkrong di kedai kopi, tetap ngobrol main gawai pasti ada. Misalnya, ada lima orang atau enam orang, satu orang pasti ada yang maniak banget dengan gawai. Tapi maniak dengan gawai ini lebih ke mengabadikan momen sih, terus sambil mengedit filter segala macam terus di post. Paling nanti ada celetukan dari teman yang lain, nanti tag saya, ya."

Informan merupakan seorang selebgram yang up to date, hampir dari keseluruhan kegiatannya di-posting, bahkan tidak ada privasi lagi. Dahulunya kamar adalah privasi, saat ini di media sosial dengan percaya diri menggunggah kegiatan demikian di kamar pribadi.

Perilaku komunikasi berarti kebiasaan komunikasi yang dilakukan sehari-hari dalam kehidupan sosial. Perilaku komunikasi milenial dan gen $\mathrm{Z}$ era digital sudah dipengaruhi oleh gawai dan akses internet yang cepat. Interaksi milenial dan gen $\mathrm{Z}$ antarsesama manusia pun mulai ada perubahan dalam dinamika sosial, apakah sebelum dan sesudah kehadiran gawai berpengaruh pada etika komunikasi kepada orang yang sedang mengajak untuk berinteraksi tatap muka (face-to-face). Dalam penelitian yang dilakukan di desa yang baru masuk signal internet, juga ada perubahan cara masyarakat berkomunikasi. Seperti penelitian yang dilakukan oleh Rizqi dan Pradana tentang dampak penggunaan smartphone bagi kehidupan sosial di Desa Ngadirojo, Kabupaten Pacitan. Mereka mengungkapkan temuan di Ngadirojo, warganya kurang berinteraksi ketika bertemu langsung dalam situasi seperti pertemuan warga, hampir setiap orang lebih memilih memainkan gawainya ketimbang bercakap-cakap langsung (Rizqi dan Pradana, 2018).

Perubahan tersebut menjadi temuan dalam penelitian Rizqi dan Pradana dan Pradana, bahwa gawai memengaruhi pola berkomunikasi warga setempat. Sementara itu, konsep yang mendukung perubahan perilaku komunikasi, menurut Kwick, perilaku adalah tindakan atau perbuatan organisme yang dapat diamati dan bahkan dapat dipelajari (Notoatmodjo, 2007). Perilaku komunikasi berarti kebiasaan 
komunikasi yang dilakukan sehari-hari dalam kehidupan sosial. Perilaku komunikasi milenial dan gen $\mathrm{Z}$ era digital sudah dipengaruhi oleh gawai dan akses internet yang cepat. Interaksi milenial dan gen $\mathrm{Z}$ antar sesama manusia pun mulai ada perubahan dalam dinamika sosial, apakah sebelum dan sesudah kehadiran gawai berpengaruh kepada etika komunikasi kepada orang yang sedang mengajak untuk berinteraksi tatap muka (face-to-face). Perilaku komunikasi milenial dan gen $\mathrm{Z}$ bisa diamati dari cara mereka berkomunikasi sehari-hari di lingkungan sosial. Ada perilaku komunikasi antara satu individu dengan individu lain yang dipengaruhi oleh kehadiran teknologi. Komunikasi face to face menjadi kehilangan makna dalam kehidupan sosial, di mana posisi face to face komunikasi lebih efektif dan mendominasi sebelum kehadiran teknologi.

Sementera itu, secara komunikasi interpersonal yaitu komunikasi antara orangorang secara tatap muka yang memungkinkan setiap pesertanya menangkap reaksi orang lain secara langsung, baik secara verbal atau pun non verbal (Mulyana, 2013). Teori komunikasi interpersonal tersebut juga ada sedikit pergeseran saat milenial dan gen $\mathrm{Z}$ di Kecamatan Kuranji, yaitu komunikasi oleh komunikan tidak direspon secara langsung, tetapi mengalami delay akibat lawan bicara menggunakan gawai. Penggunaan gawai, terutama di media social, juga dapat menurunkan kesejahteraan yang lebih buruk.

Mengingat luasnya penelitian korelasional yang menghubungkan media sosial digunakan untuk kesejahteraan yang lebih buruk, Hunt et. al. melakukan studi eksperimental untuk menyelidiki peran kausal potensial yang dimainkan media sosial dalam hubungan ini. Setelah seminggu pemantauan awal, 143 mahasiswa di University of Pennsylvania secara acak ditugaskan untuk membatasi Facebook, Instagram dan Snapchat. Gunakan hingga 10 menit, per platform, per hari, atau gunakan media sosial dan yang seperti biasa untuk tiga orang minggu. Hasilnya kelompok penggunaan terbatas menunjukkan penurunan kesepian yang signifikan dan depresi selama tiga minggu dibandingkan dengan kelompok kontrol. Kedua kelompok menunjukkan penurunan yang signifikan dalam kecemasan dan ketakutan ketinggalan dari tren sehingga menyarankan manfaat dari peningkatan pemantauan diri. Temuan tersebut sangat menyarankan bahwa membatasi penggunaan media sosial menjadi sekitar 30 menit per hari mungkin mengarah pada peningkatan kesejahteraan yang signifikan (Hunt et. al., 2018).

Jika belum bisa mengubah
permasalahan perubahan perilaku komunikasi milenial dan gen $\mathrm{Z}$ ini secara menyeluruh, bisa menguranginya dengan beberapa strategi konsep berikut dalam keluarga.

a) Mematikan semua notifikasi di gawai, jika butuh baru dilihat.

b) Menghapus semua aplikasi yang tidak terlalu penting.

c) Tidak terlalu banyak melihat informasi di media sosial dan berita, cukup sewajarnya.

d) Ada media yang direlakan untuk tidak dipakai lagi, yang menghabiskan, dan menyita banyak waktu.

e) Tidak menerima video rekomendasi Youtube.

f) Sebelum membagikan konten, perlu dipastikan konten itu benar atau hoax.

g) Perhatikan banyak orang kerja di industri teknologi. Tidak memberikan perangkat teknologi dan media sosial kepada anaknya. Tidak memberikan gawai kepada anak-anak yang belum sanggup mengatur waktunya. Membuat peraturan untuk tidak ada gawai di kamar tidur anak. 30 menit sebelum tidur, anak tidak boleh lagi menggunakan gawai dan gawai disimpan di kamar orang tua.

h) Orang tua dapat membuat aturan agar anak tidak memiliki media sosial sampai SMA.

i) Menyusun anggaran waktu bersama anak-anak, membuat aturan waktu keluarga tanpa gawai. Seperti 
membiasakan traveling bersama anak, makan malam bersama tanpa gawai, sarapan tanpa gawai.

j) Menghadirkan permainan offline di tengah masyarakat sesuai kondisi lingkungan.

Perangkat teknologi telah berhasil memengaruhi perilaku penggunanya dengan membuat orang dapat bertahan lama di layar gawai. Teknologi bisa menghadirkan dua dunia yang berbeda. Hal ini senada dengan pernyataan Roselin.

Menurut Roselin (2010), perkembangan teknologi internet tidak hanya mampu menciptakan masyarakat dunia global saat ini, tetapi juga mampu menciptakan suatu transformasi dalam ruang gerak kehidupan baru bagi masyarakat sehingga tanpa disadari manusia telah hidup dalam dua kehidupan, yaitu kehidupan masyarakat nyata dan kehidupan masyarakat maya (cyber community) (Ekasari \& Dharmawan, 2012).

Alasan adanya dua kehidupan ini membuat banyak milenial dan gen $\mathrm{Z}$ di wilayah Kuranji terlena dengan gawainya. Fenomena perubahan perilaku komunikasi yang semakin meningkat, terlebih Indonesia dan dunia umumnya sedang dilanda musib, yaitu covid-19 yang membuat manusia harus menjaga jarak dan bekerja dari rumah. Keadaan dari rumah membuat milenial dan Gen Z berkomunikasi menggunakan layanan chatting online, video call, dan berkabar di dunia cyber lebih lama. Perubahan dalam tatanan kehidupan masyarakat juga telah dirasakan milenial dan Gen Z, akibat masuknya pengaruh internet. Teknologi ini sudah dapat diakses oleh berbagai kalangan masyarakat, baik di perkotaan maupun pedesaan. Perubahan komunikasi yang begitu signifikan dirasakan adalah saat komunikasi interpersonal, tradisi sibernetika memberikan gambaran bahwa relationship merupakan entitas yang dinamis. Relationships are not static entities never change (Littlejohn \& Foss, 2011). Suatu hubungan tidak statistik yang tidak bisa berubah, tetapi hubungan itu bersifat dinamis yang bisa berubah kapan saja. Seperti fenomena perilaku milenial dan gen $\mathrm{Z}$ di lingkungan sosial seperti hasil penelitian.

Berdasarkan riset jangka panjang dari Bateson, Watzlawick, dan kawan-kawan sering dikenal Palo Alto Group memberikan penjelasan tentang komunikasi dalam konteks interpersonal, dugaan awal atau penyiapan berupa pola perilaku yang muncul dalam proses relationship yang dilakukan oleh pelaku komunikasinya. Oleh karena itu, kita dalam berkomunikasi sangat dipengaruhi oleh referensi pola perilaku yang sudah kita siapkan (Fajar, 2013). Pola perilaku sangat ditentukan dari mana referensi itu berasal, saat ini referensi yang paling banyak terjadi dari media sosial, yang menggambarkan perilaku dan bahasabahasa kekinian yang sering ditampilkan di media sosial.

Pola perilaku yang disiapkan era digital ini perilaku yang terjadi saat berkomunikasi interpersonal tidak memerhatikan lawan bicara. Ada media yang membuat milenial dan gen $\mathrm{Z}$ terus multitasking antara sedang bicara dan melakukan aktivitas lainnya di dunia maya. Respon dari komunikan tidak sebaik sebelum era digital yang langsung saling pengertian dan memerhatikan lawan bicara. Relevansi perubahan yang terjadi dengan gawai sangat berkaitan erat, melihat dari pengalaman-pengalaman inofrman yang telah dijabarkan pada hasil dan pembahasan ini.

\section{Kesimpulan}

Berdasarkan hasil penelitian yang telah dibahas bersama teori yang digunakan dalam penelitian ini dapat ditarik beberapa kesimpulan. Perilaku milenial dan generasi $\mathrm{Z}$ yang semula interaktif sebelum menggunakan gawai, setelah menggunakan gawai proses komunikasinya menjadi pasif, tidak terjadi komunikasi efektif. Berbekal pengalaman milenial dan gen $\mathrm{Z}$, era digital mengurangi komunikasi tatap muka.

Dengan kesibukan yang ada di dunia digital, milenial dan gen $\mathrm{Z}$ mendapatkan hambatan berkomunikasi sehingga tidak 
fokus dalam berkomunikasi. Perilaku komunikasi online juga menunjukkan perilaku komunikasi yang tidak jujur kepada lawan bicara yang tidak terlihat alias hanya berkomunikasi lewat dunia maya sehingga menimbulkan banyak konflik.

Perlu ada kontrol yang lebih baik dari diri pribadi milenial dan gen $\mathrm{Z}$, yakni membatasi penggunaan digital sesuai kebutuhan. Pembatasan penggunaan gawai akan sangat berarti untuk perkembangan diri milenial dan gen Z. Saran untuk orang tua, agar lebih memberikan pengawasan terhadap anak terkait memperhatikan etika menggunakan media yang tidak merugikan diri sendiri dan orang lain sesuai sepuluh saran poin yang telah peneliti sampaikan pada pembahasan.

Perubahan perilaku komunikasi ini perlu mendapat perhatian khusus dari pemerintah Kota Padang agar lebih optimal dalam mensosialisasikan program 18-21. Program 18-21 adalah program yang diselenggarakan oleh pemerintah Kota Padang untuk memperkuat komunikasi di dalam keluarga. Maksud dari 18-21 adalah pada pukul 18:0021:00 meningkatkan komunikasi dengan keluarga dengan kegiatan salat berjamaah maghrib dan isya berjamaah, makan malam bersama, non-aktif (gawai dan elektronik), dampingi anak belajar dan berdiskusi (Marlina, 2020). Program 18-21 belum optimal dilaksanakan di Kuranji dan masih banyak keluarga yang belum menerapkan program ini untuk memperkuat komunikasi.

Begitu juga kepada pemerintah pusat dan tokoh masyarakat dalam kaderisasi generasi positif yang terhindar dari perilaku menyimpang dan antisosial. Mengantisipasi lebih baik daripada banyak korban kecanduan gawai yang mengubah sistem sosial.

\section{Daftar Pustaka}

Adiarsi, G. R., \& Silsa, H. (2018). Fenomena Bergabungnya Anak Muda Jakarta ke dalam Organisasi Sinergi Muda Secara Suka Rela. Profetik: Jurnal Komunikasi, $\quad 11(2), \quad 99$. https://doi.org/10.14421/pjk.v11i2.147 4

Afrizal. (2017). Metode Penelitian Kualitatif. PT Rajagrafindo Persada.

Arifin, B. S. (2015). Psikologi Sosial. Pustaka Setia.

Aswar. (2020). Efek Kemampuan Komunikasi Terhadap Perilaku Agresi Orang Tua Kepada Anak. MEDIALOG:Jurnal Ilmu Komunikasi, https://doi.org/DOI:

https://doi.org/10.35326/medialog.v3i2. 744

Aw, S. (2011). Komunikasi Interpersonal. Graha Ilmu.

Budiati, I. D. (2018). Profil Generasi Milenial.

Daryanto, M. R. (2016). Teori Komunikasi. Penerbit Gava Media.

Effendi, N. (2019, November). Merindukan Budaya Interaksi Alamiah. Surat Kabar Padang Ekspres.

Ekasari, A. H. (2012). Dampak SosialEkonomi Masuknya Pengaruh Internet dalam Kehidupan Remaja Pedesaan. Jurnal Sosiologi Pedesaan, 10(2), 57. https://doi.org/https://doi.org/10.31315/ jik.v10i2.129

Fajar, A. (2013). The Relationship: Kunci Relasi dalam Interpersonal Context (Pemetaan Tradisi Teori Komunikasi mengenai Komunikasi Interpersonal dalam Pandangan Stephen W. Littlejohn). KomuniTi, 25.

Fauziyyah, S. N. \& Rina, N. (2020). Literasi Media Digital: Efektivitas Akun Instagram @infobandungraya terhadap Pemenuhan Kebutuhan Informasi Followers. Medialog: Jurnal Ilmu Komunikasi, , 13-24, https://doi.org/https://doi.org/10.35326/ medialog.v3i1.479

Francis, T. and H F.. (2018). 'True Gen': 
Generation $\mathrm{Z}$ and its implications for companies. McKinsey \& Company.

Hidayatullah, S., Devianty, R. C.;, \& Wibowo. I. A. (2018). Perilaku Generasi Milenial dalam Menggunakan Aplikasi Go-Food. Jurnal Manajemen \& Kewirasusahaan, 6 (2), 240-249. https://doi.org/https://doi.org/10.26905/ jmdk.v6i2.2560

Hunt, M. G., Marx, R., Lipson, C., \&Young, J. (2018). No More FoMO: Limiting Social Media Decreases Loneliness and Depression. Journal of Social and Clinical Psychology, 37(10), 751-768.

Kuswarno, E. (2013). Metodologi Penelitian Komunikasi Fenomenologi. Widya Padjajaran.

Littlejohn, S. W. \& Foss, K. A. (2011). Theories of Human Communication, Tenth Edition (p. 230). Wadworth.

Littlejohn, S. W. \& Foss, K. A. (2009). Encyclopedia of Communication Theory. Sage Publication, Inc.

Marlina, F. (2020). Berhadiah Umroh, Program Implementasi 18-21 Kota Padang Kembali Digelar. https://news.klikpositif.com/baca/6308 0/berhadiah-umroh-programimplementasi-18-21-kota-padangkembali-digelar

Mcquail, D. (2011). Teori Komunikasi Massa Mcquail, Edisi 6 (6th ed.). Sage Publication Asia-Pacific Pte Ltd.

Mulyana, D. (2013). Ilmu Komunikasi Suatu Pengantar. PT Remaja Rosdakarya.

Nasrullah, R. (2014). Teori dan Riset Media Siber (Cybermedia). Prenadamedia Group.

Ngafifi, M. (2014). Kemajuan Teknologi dan Pola Hidup Manusia dalam Perspektif Sosial Budaya. Jurnal Pembangunan Pendidikan: Fondasi dan Aplikasi, 2(1).

Notoatmodjo, S. (2007). Promosi Kesehatan dan Ilmu Perilaku. Rineka Cipta.
Nur, E. (2017). Perilaku Komunikasi antara Guru dengan Siswa Broken Home. Jurnal Penelitian Komunikasi, 20(2), 161-174.

https://doi.org/10.20422/jpk.v20i2.272

Putra, Y. S. (2016). Teori Perbedaan Generasi. Among Makarti.

Qurniawati, R. S., \& Nurohman, Y. A. (2018). eWOM pada Generasi Z di Sosial Media. Jurnal Manajemen Dayasaing, 20(2), 70-80. https://doi.org/https://doi.org/10.23917/ dayasaing.v20i2.6790

Rizqi, M. \& Pradana, B. C. S. A. (2018). Literasi Dampak Penggunaan Smartphone bagi Kehidupan Sosial di Desa Ngadirojo, Kabupaten Pacitan. Communicare, 5(2), 15-30. https://doi.org/https://doi.org/10.37535/ 101005220182

Saleh, G. \& Pitriani, R. (2018). Pengaruh Media Sosial Instagram dan WhatsApp Terhadap Pembentukan Budaya "Alone Together." Jurnal Komunikasi, 10(2). https://doi.org/10.24912/jk.v10i2.2673

Severin, J. W. (2014). Teori Komunikasi : Sejarah, Metode dan Terapan di Dalam Media Massa. Prenadamedia Group,.

Syahputra, I. (2017). Paradigma Komunikasi Profetik Gagasan dan Pendekatan. Simbiosa Rekatama Media.

Takariani, C. S. D. (2011). Studi Eksplanatori Survei tentang Pengaruh Chatting melalui Facebook terhadap Komunikasi Tatap Muka Remaja dalam Keluarga di Provinsi Jawa Barat dan Banten. Jurnal Penelitian Komunikasi, 14(2), 128.

Triantoro, D. A. (2019). Konflik Sosial dalam Komunitas Virtual di Kalangan Remaja. Jurnal Komunikasi, 13(2), 135150.

https://doi.org/https://doi.org/10.20885/ komunikasi.vol13.iss2.art2

Tubbs, S. L., \& Moss, S. (2012). Human 
Communication Prinsip-Prinsip Dasar. PT Remaja Rosdakarya.

Wicaksono, A. \& Irwansyah, I. (2017). Fenomena Deindividuasi dalam Akun Anonim Berita Gosip Selebriti di Media Sosial Instagram. Profetik: Jurnal Komunikasi, $\quad$ 10(2), 34-45. https://doi.org/https://doi.org/10.14421/ pjk.v10i2.1335

Zorn, R. L. (2017). Coming in 2017: A New Generation of Graduate Students-The $\mathrm{Z}$ Generation. College and University; Washington, 92(1), 61. 